\title{
University Library Service to the General Public ${ }^{1}$
}

$\mathrm{T}$ EACHING is the principal function of colleges and universities. It is their reason for being, and they have nearly a complete monopoly on the teaching of young adults. Research is almost as important in the academic scheme of things. If the faculty is at all active, it is bound to contribute to knowledge. Professors being subject experts, they are not content to repeat what they learned in their student days. Universities have long been considered knowledge factories. Even now, when large corporations maintain their own research organizations, the universities lead in producing new knowledge as well as in summarizing what was previously known.

Teaching and research are public services which take place on the campus. In the course of time the universities have developed other functions outside their bailiwick, in response to public demands or as a result of social reform movements. To a greater or less extent all universities advise governments, corporations, and individuals, inform them, and help them devise practical applications of knowledge. Probably all universities rank these off-campus services below teaching and research, however. Teaching comes first. If we did not know that before, we see it now, when research men are being drafted into classroom teaching because of the abnormally large enrolments. Research comes second. The university's reputation rests upon it in the long run. Its priority over other public serv1 Paper presented at the meeting of the Association
of College and Reference Libraries, Buffalo, June I8, of Colle. ices can be seen in endowed universities, which have no axe to grind with the general public. Off-campus service ranks third, partly because it is a new development, partly because it is not something which a university alone can do, and partly because the university is at a disadvantage when it leaves its laboratories and libraries.

For these same reasons, universty librarians rank service to the general public third. The library has more than enough to do on the campus. It is chronically shorthanded, because the library grows whether the university does or not. New teaching methods require more of the staff as time goes on. Research complicates the routines of acquisition, cataloging, and service by requiring quantities of materials difficult to arrange and use. The general public has its own libraries, moreover-public, state, school, and special libraries-organized and maintained to serve all people or certain groups of them. With plenty to do on the campus, the university librarian naturally pays little attention to a field of endeavor which belongs to other kinds of libraries.

The neglect of off-campus service can be traced clearly, even in the activities for which the university library has a direct responsibility-extension teaching and agricultural extension. Agricultural extension and library service have yet to be successfully combined. Universities have combined library service with extension teaching more successfully. The extension division of some institutions operates its own library, supplementing its resources from 
the general library. Indiana University and a few others maintain branch libraries in their extension centers. As a general rule, however, the extension student receives more help from local and state libraries than he does from the university library. Wilson and Tauber conclude their description of library service to extension students by saying:

Campus needs take precedence over offcampus requests, and only those materials that are not in demand for course work on the campus may be sent out as extension loans. Difficulties are encountered when the same courses are given on the campus and by the extension division at the same time. Sorenson has pointed out how the lack of library facilities had hindered effective extension teaching. ${ }^{2}$

\section{Other People}

If the university's off-campus students receive little attention from the library, other people naturally figure still less in the library's activities. Yet a fair number of them ask the library for service because they look upon the library as a great repository which belongs to the people, either directly through state ownership or indirectly as a public institution. The university librarian regards these requests with sympathy or apathy according to the pressure of work on the campus and the policy of the institution. He may refuse all requests except those from other universities, from whom he borrows. He may go to the opposite extreme by competing with state and local libraries. Or he can take a middle ground by not altogether refusing outside requests but also not encouraging them.

$\mathrm{U}_{\mathrm{p}}$ to now the demands from off the campus have not greatly burdened most university libraries. Few academic libraries lend as many books off campus in a year as

\footnotetext{
2 Wilson, Louis $\mathrm{R}$, and Tauber, Maurice $\mathrm{F}$. The University Library. 'Chicago, University of Chicago Press, 1945, p. 219.
}

they do on campus in a day. But this state of affairs appears due for a change. The Adult Education Journal, in its January issue, reports a "heavy upsurge" in adult educational activities, arriving sooner after the war than was anticipated. Despite the handicaps of long teaching hours and inconvenient schedules, the faculty will probably enter into public affairs more actively during the next few years, impelled by a desire to inform the public of the implications of the atomic bomb and to lead discussions on the nation's vital stake in international affairs. As study groups turn to scientific and political questions, we may expect a greater demand for books and information than public libraries can altogether satisfy. Special libraries and subject departments in public libraries will probably want more rather than less interlibrary loans and microfilms as time goes on, since they rely upon large general libraries for out-of-the-way and seldom-used publications.

\section{An Inconvenient Time}

An increased demand for off-campus service could hardly come at a more inconvenient time. Nearly all universities have record enrolments. The shortage of trained librarians hampers the process of stretching the library's services to meet a larger student body. The veterans require more of the library than other students because, like summer school students, they take education more seriously. Many university librarians will undoubtedly conclude that they cannot spare as much time as formerly for interlibrary loans, let alone other extension services, and will postpone a solution of the unsolved problem of serving that forgotten man, the extension student. Others will probably experience a strong temptation to promote off-campus service, in spite of the difficulties involved in attempting to 
satisfy the multitudinous and multifarious book needs of the general public. Particularly in the South and the West, the university occupies a unique position among adult education agencies, and the library shares the university's eminence and distinction. It is usually one of the largest libraries in its neighborhood. It has more books on more subjects than other libraries usually do, and it has kinds of books other libraries do not have. When answering reference questions, it has access to a large group of subject experts-the faculty-and a more varied reference book collection.

\section{Ideal Supplementary Agency}

Because it has so many books, so many kinds of books, and such unusual reference resources, the university library is ideally equipped to supplement other libraries. Since it has no compelling obligation to serve the general public, obviously the university library should cooperate with the libraries which do have this obligation, not compete with them. A considerable number of university librarians have not drawn this moral from the circumstances of off-campus service. Some of them compete with state extension agencies. This is happening now, to some extent, in North Carolina and South Carolina. The University of North Carolina has the excuse that it is not in the same city as the state agency. The University of South Carolina does not have that excuse. In some states this duplication is unintentional and even desirable, because the state extension agency is new or ineffectual. On the other hand, competition with a local library is difficult to avoid but harmful. Librarians in Oregon, for example, believe that the university has stunted the growth of the Eugene Public Library.

The University of Wisconsin sets a good example of cooperation. The main library lends books directly to college libraries and public libraries. It also lends to public libraries and to individuals through the free library commission. The university departmental libraries lend books and answer questions for special types of individuals, such as farmers, doctors, extension students, high-school debaters, and clubwomen. They avoid duplication, as well as they conveniently can, by referring requests to each other and to the free library commission. All these campus libraries and the commission send their loans to the local library, where there is one, instead of directly to the borrower. This network of cooperation sounds complicated, but in practice it works easily and simply. The university's book resources and many technical and advisory services are available to every citizen of Wisconsin.

\section{Interlibrary Lending}

Another example of cooperation is the interlibrary lending which goes on all over the country. Interlibrary loans and microfilms have become standard practice among American libraries. To be sure, they often come too late and sometimes not at all, so there is room for improvement here. The interlibrary loan code hinders rather than helps, by stressing the library's convenience rather than the library client's satisfaction. Fortunately, most librarians ignore it. Despite delays and difficulties, interlibrary loans probably get the right book to the right man more often than not.

We have three examples of cooperation which improve on the Wisconsin arrangement and greatly facilitate interlibrary lending. These are the bibliographic centers in Denver, Seattle, and Philadelphia. The Institute on Bibliographic Centers brought out the fact that the client of a bibliographic center fares better than a library user elsewhere, even where libraries 
cooperate as well as they do in Wisconsin. The Wisconsin citizen, for example, may borrow the books in his local library, the free library commission's traveling library, and the university library. If the book is not in any of these collections, he does not get it, because $\mathrm{W}$ isconsin has no union cata$\log$ and does not forward requests to libraries outside the state. Reference questions go through the same channel, and sometimes bring replies, sometimes do not. The library client in the territory of a bibliographic center stands a much better chance of getting the book or the information he wants-in fact, over nine chances in ten.

The bibliographic center is a substitute for a universal library. It has few books of its own, but it has a union catalog to show where a great many books are located. It coordinates reference service, answering some questions and referring others to the libraries best equipped to answer them. In Wisconsin the libraries have joined an alliance. The bibliographic center goes a step beyond this by bringing libraries into a confederation. While each library maintains its independence, it has become, in a sense, one section of a regional collection, one branch of a regional reference department. University libraries in the territory of a bibliographic center are spared the trouble of organizing their public services from the outside in. They cooperate with other libraries effectively and they serve the general public efficiently.

\section{Financing Service to Public}

Incidentally, bibliographic centers bring out into the open the crucial question about public service- How is it to be financed? The centers are supported by the member libraries. When they ask a university for a contribution, the librarian must ask the administration to help finance an agency which serves the general public as well as university people. University libraries do spend money for public service, in any event, by using staff time and wearing out their books for people off the campus. However, they spend relatively little in this way, and that little is not itemized in the budget. The libraries which cooperate through a bibliographic center lend far more books than they otherwise would. In return they borrow more, as soon as the faculty and the students discover that they can borrow from other libraries without the usual delays and disappointments. Perhaps the improved borrowing service justifies the additional lending costs and the bibliographic center's fee. If not, the fee emphasizes the fact that the library has embarked on a program of general public service. It brings offcampus service out into fiscal daylight.

Is the university justified in spending its funds for this purpose? University policy or tradition may have answered this question long ago, as they have in most state colleges and universities. The librarian of an endowed institution might argue that offcampus library service represents a return to the public for tax exemption and the interest on endowment, which comes out of the public's current earnings. He might also reason that off-campus library service resembles the lectures, advice, and information which other university departments give to the public or offer at a small fee. Some university librarians now solve the financial question by charging a fee for offcampus service. The University of California, for example, charges one for interlibrary loans. Others follow public library practice in asking nonresidents to pay for the privilege of borrowing books. Certain large public libraries have found another method for financing special services. The Boeing Aircraft Company supports an aviation collection in the Seattle Public Library, 
for example, and Colorado engineers help support the science and technology department of the Denver Public Library. The answer to the financial question, in other words, may be found outside the university as well as inside.

\section{Justification for Service}

Judging by a recent conference in Chicago, the university librarian will also find outside the campus the justification for service to the general public. He will discover that the general public consists of many special interests which do not now obtain the kind and quantity of library service they require. Marian C. Manley sent excerpts from the proceedings of the business and industry library investigation, which is the report of a conference held in Chicago in March. Her notes boil down to the conclusion that university libraries own quantities of material and have access to expert guidance which business firms need even though they have their own special libraries. This is so because a corporation's interests are broader than its own library's subject field.

One speaker at the Chicago conference said :

There is one thing here I wish you would speak about. Some of these marketing and economic questions come over into the field of social science, and a great many of the sociologists are concerned with things in the field of marketing and statistics. In the university, you probably have the finest collection of sociological material there is. Have you any ideas of how that material might be made available?

To this a librarian replied:

The greatest demand is for the class of material already referred to as "fugitive." We, like every other library in the city, have an unknown number of tons of it on hand, and it is certainly being put to only a fraction of the use to which I suppose it is capable of being exploited. There are great quantities of material in the city, but scattered. The main problem seems to me to be the exploitation of what we have. In the field of chemistry there are a good many titles and, in terms of the ease with which those materials can be consulted, we have less to show than, say, Washington, where you can get around more easily, where the ties among the libraries are closer. It seems to me to be very largely a question of service. I listen with a good deal of interest and I am appalled at the range that was suggested. One might hope to make a frontal attack on a small field to do the job neatly and efficiently, but to broaden the front to include even the interests represented here seems to me quite a job. I dare say a substantial number of associations and societies in it all have their own libraries. I have no doubt there are great quantities of materials at the unversity which are by no means as fully used as they could be if channels for getting at them were better developed.

These remarks at the Chicago conference show that service to the general public offers a really challenging opportunity to improve the quantity and quality of library service in the university's territory. The university library has some of the materials and expert assistance which professional and businessmen need. Miss Manley's notes also point out that public service gives the university library access to additional sources of information. By enlarging its clientele, the university library gets in touch with experts on subjects not in the curriculum. The bibliographic centers and the large public libraries show that the university may also profit by fees and special collections. Someone must bear the cost of this additional service. Probably most organizations will pay for their share, once they know its value.

The Chicago conference also points out that public service is complex and difficult. The public includes a wide variety of people and organizations who need many sorts (Continued on page 318 ) 
which, it is expected, will become available each year about the time of the General Assembly session in September.

,

At the present time, plans for two publications other than documents are well advanced. One is a weekly bulletin containing regular accounts of the activities of the United Nations, of its various branches and related agencies, background articles on topics under discussion, biographical notices on delegates and officials, and a bibliographical section. The other is a United Nations yearbook which will include, among other things, a chronology of United Nations activities, an account of the work achieved by each organ, with the resolutions passed, the structure of the United Nations, with the names of delegates and officials, a who's who, a list of publications issued during the year, a calendar of forthcoming United Nations events, and basic texts such as the Charter, together with amendments, if any. Both of these publications will be issued by the Department of Public Information.

It is likely that in addition there will be specialized and technical publications, for example a treaty series to take the place of the treaty series issued by the League of $\mathrm{Na}$ tions.

All publications of the United Nations intended for public distribution will be available from Columbia University Press, International Documents Service, 2960 Broadway, New York City 27.

\section{University Library Service to the Public}

\section{(Continued from page 3 ro.)}

of assistance. The university library's clientele seems homogeneous in comparison. The university library is no better equipped to satisfy all sorts of people than the public libraries and special libraries are. All three together, however, can greatly widen the range of available library resources and, by coordinating their activities, greatly speed up and improve the quality of their services. University library service to the general public at present plays a minor role, because it is normally something merely permitted or good-naturedly agreed to. But when we face it and look at its implications, we recognize that it is actually the old problem of how to organize libraries of all kinds into a coordinated system. An old problem, it has greater urgency now than ever before because the times are urgent. It is a problem which challenges us as members of the library profession. As librarians and as citizens, university librarians have the opportunity, if not the duty, to send out the library's resources and services to inform and guide the American people.

\section{Must Serve Public}

We university librarians have three distinct clienteles-the students, the faculty, and the general public, including extension students. During the next few years we may be tempted to ignore this third clientele altogether. If we do, we can justify ourselves on the ground that we already have more than enough to do on the campus; but this atomic age gives us an exceptional opportunity, if we care to take advantage of it. We have the opportunity to provide some of the information the American people need in charting their course through this crisis. It is not our job to supply most of what they require, but rather to supplement and help coordinate the service by other libraries.' We shall profit by cooperation in many ways, particularly by advancing our profession and the common good. 